\title{
Age and regional significance of Brachiopods from the Temiscouata Formation of Madawaska County, New Brunswick
}

\author{
C. St. Peter, New Brunswick Department of Natural Resources \\ P.O. Box 6000, Fredericton, N.B., Canada E3B $5 H 1$ \\ and \\ A.J. Boucot, Department of Geology \\ Oregon State University, Corvalizs, Oregon, U.S.A. 97331
}

\begin{abstract}
The Lower Devonian Temiscouata Formation of Madawaska County, northwestem New Brunswick forms part of a more extensive slate belt that extends from eastern Gaspé Peninsula to Long Island Sound. The age of the basal beds of slates correlated with the Temiscouata Formation has been previously dated as New Scotland (late Gedinnian). Until now, the youngest age assigned to the slates has been Oriskany (late Siegenian) based on the brachiopod Leptocoelia flabellites. The discovery of two previously unreported genera in New Brunswick - Eodevonaria and Plicanopliaand the taxonomic reclassification of Leptocoelia flabellites indicates that the Temiscouata Formation extends upwards into the Esopus or Schoharie (early to middle Emsian). Regional correlation fixes the upper age of the Temiscouata as pre-Onondagan (pre-Eifelian). The new age assignment allows the lower age limit of the Acadian Orogeny in this part of the Appalachians to be raised to post-Esopus or Schoharie time.
\end{abstract}

\begin{abstract}
D'âge dévonien inférieur, la formation de Témiscouata (nord-ouest du Nouveau-Brunswick, comté de Madawaska) fait partie d'une vaste bande d'ardoises qui s'étend de l'est de la péninsule gaspésienne jusqu'au détroit de Long Island. Auparavant, on datait les couches d'ardoises basales, corrélatives avec la formation de Témiscouata, comme étant d'âge new scotland (gédinnien tardif). Jusqu'à présent, basé sur la présence du brachiopode Leptocoelia flabellites, le plus jeune âge attribué aux ardoises était oriskany (siégénien tardif). La découverte de deux genres précédemment inconnus au Nouveau-Brunswick, Eodevonaria et Plicanoplia, ainsi que la reclassification taxonomique de Leptocoelia flabellites, prouvent que la formation de Témiscouata remonte jusqu'aux âges ésopus ou schoharie (bas à moxen emsien). Une corrélation régionale fixe l'âge supérieur de la formation de Témiscouata comme pré-onondagien (pré-eifelien). L'attribution de ce nouvel âge permet d'élever la limite d'âge inférieure de l'orogenèse acadienne dans cette partie des Appalaches jusqu'aux temps post-ésopus ou schoharie.
\end{abstract}

[Traduit par le journal]

\section{INT RODUCTION}

Reconnaissance mapping (sponsored by the New Brunswick Department of Natural Resources and Department of Regional Economic Expansion) of Ordovician, Silurian and Devonian sedimentary rocks was carried out in Madawaska and western Restigouche Counties, northwestern New Brunswick during the summer of 1975. Significant fossil discoveries were made in the Lower Devonian Temiscouata Formation. The relationship of the Temiscouata strata to its bounding rocks is reviewed and the regional implications of the new fossils are discussed.

\section{REGIONAI STRATIGRAPHY}

The bedrock geology of Madawaska and western Restigouche Counties,

MARITIME SEDIMENTS AND ATLANTIC GEOLOGY $17,88-95$ (1981)
New Brunswick (Fig. I) was examined in an attempt to delineate rock formations previously defined in the Restigouche River area to the northeast (St. Peter 1978). These formations comprise a sequence of Ordovician to Devonian sedimentary rocks within the Gaspé rrough (Poole 1967, 1976) that form lithological belts known to extend as far northeast as eastern Gaspë Peninsula (Skidmore 1967) and as far southwest as Long Island Sound (Boucot 1970, Williams 1978).

In New Brunswick, the base of the section is defined by the ordovician Grog Brook Group - a clastic turbidite sequence of slate, sandstone, minor greywacke and conglomerate. The Grog Brook strata interfinger with, and are gradationally overlain by calcareous flysch (limestone and calcareous slate) of the Upper Ordovocian to 


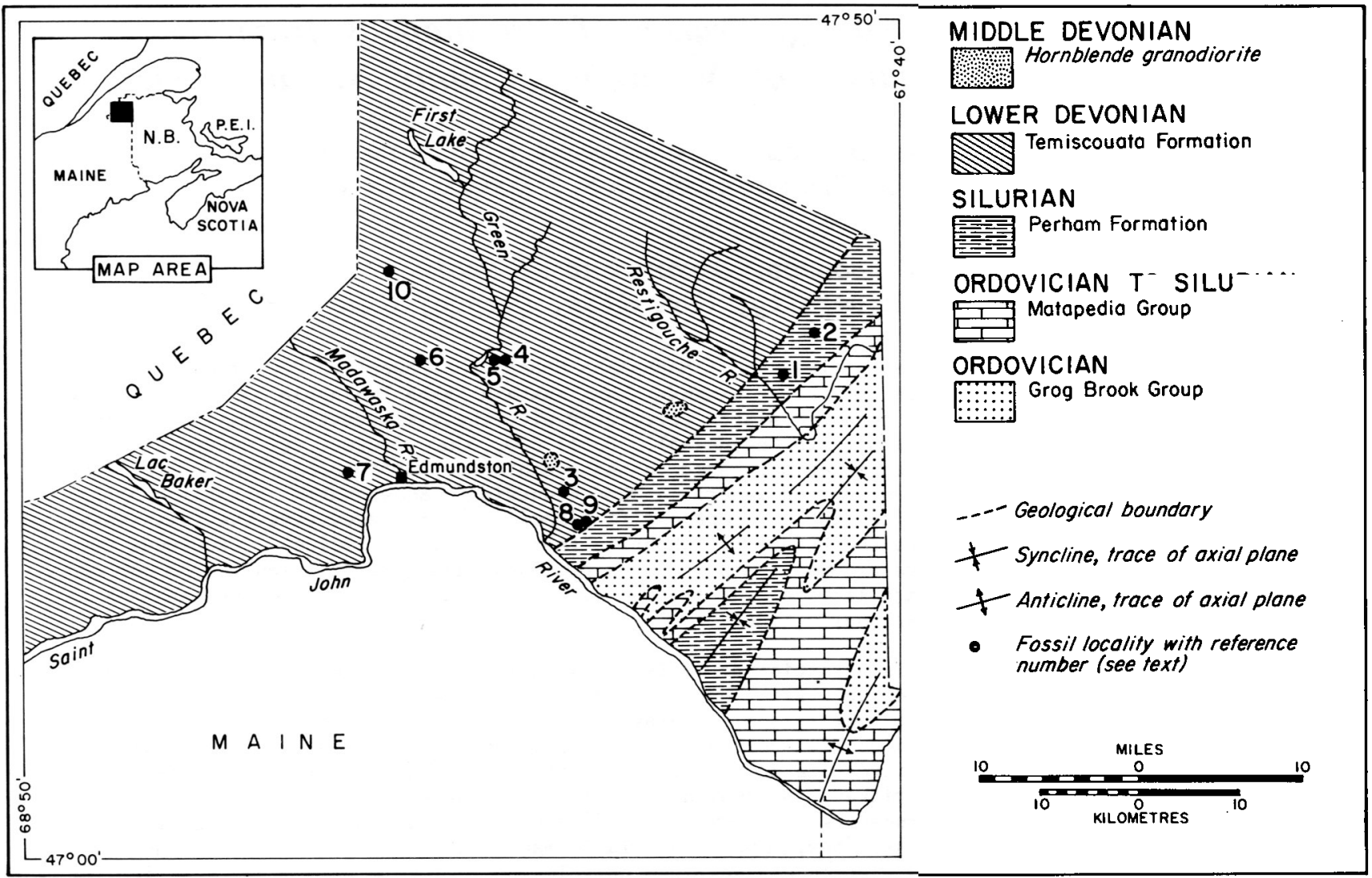

Fig. 1 - Geology of Madawaska County, New Brunswick.

Lower Silurian Matapedia Group. The Matapedia rocks are overlain by green slate, sandstone, minor red slate, lithic wacke and limestone of the Silurian Perham Formation. The Devonian Temiscouata Formation, comprising grey slate, siltstone, minor sandstone and conglomerate, overlies the Perham Formation. The Temiscouata rocks are intruded by two small stocks of hornblende granodiorite.

Perham Formation

The distribution of the Perham Formation in Madawaska county is outlined on Figure 1. The formation comprises mostly green slate and fine-grained calcareous sandstone with minor beds of red slate, dark grey slate, coarse-grained volcanogenic sandstone, graptolitic siltstone and argillaceous limestone. Iron- and manganeserich slate is commonly associated with red slate in the lower part of the section (Hamilton-Smith 1970).

Graptolites collected several hundred metres below the upper contact indicate a ludlow age for the Perham Formation. At locality 1 (Fig. 1), Pristiograptus ef. P. tumescens is middle to late Ludlovian (Rickards 1976). At locality 2, an early Ludlovian age is indicated by Colonograptus cf. $C$. roemeri (Barrande), Saetograptus cf. S. varians (Wood), and Saetograptus $c f$. S. incipiens (Wood).

The Perham Formation in northwestern New Brunswick can be correlated with lithologically similar rocks in the Ashland Synclinorium immediately to the southwest in Maine. There, the Perham rocks, which have been examined in detail and elevated to group status by Roy and Mencher (1976), 
are divided into the basal Middle llandoverian to Wenlockian New Sweden Formation and the overlying Wenlockain to early Ludlovian Jemtland Formation. In the same area, the Perham Group is conformably overlain by the Fogelin Hill Formation comprising green and red slate, and interbedded fine-grained greywacke and siltstone. The Fogelin Hill rocks range in age from early Ludlovian to possibly siegenian.

It now seems clear that the Perham Formation of St. Peter (1978) comprises beds of both the Perham Group and Fogelin Hill Formation. Red slate mapped as Perham Formation in northwestern New Brunswick occupies the proper stratigraphic position (above the Ludlovian graptolitic beds) to suggest correlation with the red slate-bearing Fogelin Hill Formation in Maine.

The uppermost beds of the Perham Formation in New Brunswick consist of green slate and interlayered quartzose sandstone. These beds pass gradationally into interbedded dark grey slate and feldspathic sandstone of the Lower Devonian Temiscouata Formation. Hence, the presence of a disconformity between the Perham and Temiscouata Formations, as suggested by the lack of Pridolian and Gedinnian fauna (St. Peter 1978), is not supported by the stratigraphic evidence.

Temiscouata Formation

The Temiscouata Formation is part of a widespread northeast-trending belt of Devonian slates which occupy the axial zone of the Gasper Trough. Several names have been used in different parts of the belt to designate this essentially homogeneous suite of rocks. The term "Temiscouata Group" was introduced by McGerrigle (1934) to describe the sequence in the lake Temiscouata area of Quebec. The name was later changed to Temiscouata Formation by Lespérance and Greiner (1969) and has been extended to incorporate lithologically similar rocks underlying northwestern New Brunswick (st. Peter 1978). East of the Matapedia Valley in Gaspé the slates are included in the Fortin Group; in northwestern Maine, equivalent slates are referred to as the Seboomook Formation, and in the Eastern Townships of Quebec the name St. Juste Group (Béland 1957) is applied.

In New Brunswick, the major rocks in the belt are dark grey slates and siltstones that weather dark grey or rusty brown. Both rock types have vague, light grey silty or sandy, discontinuous parallel laminations or color bands. The rocks are locally calcareous; some are argillaceous limestone, the carbonate content of which weathers readily leaving the rocks with a silty texture.

Light grey to medium grey interbeds of greywacke and feldspathic sandstone are common in the New Brunswick section. The greywacke beds are typically graded and contain angular clasts of slate, felsic igneous rock fragments, feldspar and quartz. Feldspathic sandstone layers are typically ungraded and have parallel, black, carbonaceous laminations and discshaped clașts of dark grey slate.

A few interbeds of conglomerate are also associated with greywacke and slate. The conglomerate is polymictic with pebbles and cobbles of quartz, quartzite, chert felsic rock fragments, slate, greenstone, granite, and gneiss set in a matrix of sandy mud. Most of the pebbles are well rounded but flattened parallel to the cleavage.

Determination of the internal stratigraphy of the Temiscouata 
Formation, as pointed out by Lespérance and Greiner (1969) in the Squatec-Cabano area and by Skidmore (1965) in correlative rocks of the Fortin Group of eastcentral Gaspé, is a difficult problem. This is largely a result of widespread penecontemporaneous deformation (contortions, convolutions), slump structures and the absence of marker horizons. The problem is further complicated in many areas by the presence of smallscale tectonic folds.

The Seboomook Formation in the Matagamon Lake area of northern Maine is lithologically similar to the Temiscouata Formation of New Brunswick (Hall et al. 1976). The bedforms and penecontemporaneous deformational structures of the rocks in that area led Hall et $a$. . (op. cit..) to conclude that the slates represented prodelta marine slope deposits.

AGE OF MADAWASKA COUNTY TEMISCOUATA FORMATION FOSSILS

The Temiscouata slates of Mada- waska county are dated by new brachiopod discoveries located in beds possibly several hundreds or even thousands of metres above the base of the formation. The extreme penecontemporaneous and tectonic folding the rocks have undergone renders it impossible to determine the exact stratigraphic position of the fossils. The important genera Plicanoplia and Eodevonaria (Fig. 1, localities 6 and 10, and Table 1). are known only from beds of Esopus and Schoharie (early Emsian) age in eastern North America (Fig. 2). Plicanoplia is not known with certainty elsewhere in the world. Eodevonaria is common in the Lower Devonian of Europe where it is characterized by a large species that cannot be confused with the small specimens present in North America, including the single specimen found by st. Peter at locality 6. Pacificocoelia (localities 5 and 8 ) has a much longer Devonian range from mid-Helderbergian through a large part of the Onondaga (late Gedinnian to Eife-

\section{TABLE I}

List of Brachiopods from Temiscouata Formation of New Brunswick

\begin{tabular}{|c|c|c|c|}
\hline $\begin{array}{l}\text { Locality. No. } \\
\quad(\text { Figure } 1)\end{array}$ & $\begin{array}{c}\text { G.S.C. } \\
\text { Locality No. }\end{array}$ & Coordinates & Fauna \\
\hline 4 & 93036 & $\begin{array}{l}47^{\circ} 28^{\prime} 28^{\prime \prime N} \\
68^{\circ} 11 \cdot 30^{\prime \prime W}\end{array}$ & leptocoelid \\
\hline 5 & 93037 & $\begin{array}{l}47^{\circ} 28^{\prime} 20^{\prime \prime N} \\
68^{\circ} 12 \cdot 15^{\prime \prime} \mathrm{W}\end{array}$ & Pacificocoelia sp. \\
\hline 6 & 93049 & $\begin{array}{l}47^{\circ} 28^{\prime} 10^{\prime \prime N} \\
68^{\circ} 18^{\prime} 30^{\prime \prime} \mathrm{W}\end{array}$ & $\begin{array}{l}\text { Eodevonaria sp. } \\
\text { unidentified brachiopod fragments }\end{array}$ \\
\hline 7 & 93051 & $\begin{array}{l}47^{\circ} 22^{\prime} 15^{\prime \prime} \mathrm{N} \\
68^{\circ} 23^{\prime} 50^{\prime \prime} \mathrm{W}\end{array}$ & $\begin{array}{l}\text { large spiriferid which is possibly } \\
\text { Howellella gaspensis }\end{array}$ \\
\hline 8 & 93052 & $\begin{array}{l}47^{\circ} 19^{\prime} 15^{\prime \prime N} \\
68^{\circ} 05^{\prime} 40^{\prime \prime} \mathrm{W}\end{array}$ & $\frac{\text { Pacificocoelia }}{\text { stropheodontid, crinoidal debris }}$ \\
\hline 9 & 93053 & $\begin{array}{l}47^{\circ} 19^{\prime} 25^{\prime \prime N} \\
68^{\circ} 20^{\prime} 55^{\prime \prime} \mathrm{W}\end{array}$ & $\begin{array}{l}\text { leptocoelid, gastropod, } \\
\text { stropheodontid. Discomyorthis, } \\
\text { sp.' Howellella cf. gaspensis }\end{array}$ \\
\hline 10 & 93055 & $\begin{array}{l}47^{\circ} 33^{\prime} 12^{\prime \prime N} \\
68^{\circ} 20^{\prime} 55^{\prime \prime W}\end{array}$ & $\begin{array}{l}\text { Plicanoplia sp. large spiriferid } \\
\text { which is possibly Howellella } \\
\text { gaspensis, large rhynchonellid }\end{array}$ \\
\hline
\end{tabular}




\begin{tabular}{|c|c|c|c|c|c|c|c|c|c|}
\hline & & $\begin{array}{l}\text { Standard } \\
\text { Section }\end{array}$ & & $\begin{array}{l}\text { American } \\
\text { Section }\end{array}$ & Range & $\begin{array}{c}\text { of } T \\
\text { Bra }\end{array}$ & $\begin{array}{l}\text { isc } \\
\text { iop }\end{array}$ & $\begin{array}{l}\operatorname{ta} 1 \\
\operatorname{Tax} a\end{array}$ & mation \\
\hline \multirow{13}{*}{ 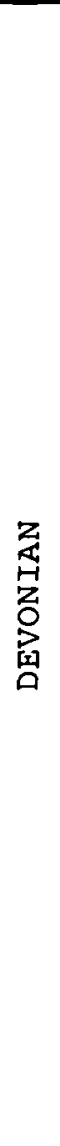 } & \multirow{4}{*}{ 㖾 } & \multirow{2}{*}{ Famennian } & & Conewangoan & \multirow{13}{*}{$\begin{array}{c}0 \\
-1 \\
-1 \\
0 \\
0 \\
0 \\
0 \\
0 \\
.-1 \\
-1 \\
-1\end{array}$} & \multirow{13}{*}{$\begin{array}{l}0 \\
-7 \\
0 \\
0 \\
0 \\
0 \\
0 \\
0 \\
0 \\
0.9\end{array}$} & \multirow{13}{*}{$\begin{array}{l}0 \\
-1 \\
-1 \\
0 \\
0 \\
0 \\
0 \\
+1 \\
0.1 \\
0 \\
01\end{array}$} & \multirow{13}{*}{$\begin{array}{l}0 \\
-7 \\
-1 \\
0 \\
0 \\
0 \\
0 \\
0 \\
.4 \\
-4 \\
-1 \\
0 \\
0 \\
\infty\end{array}$} & \multirow{13}{*}{ 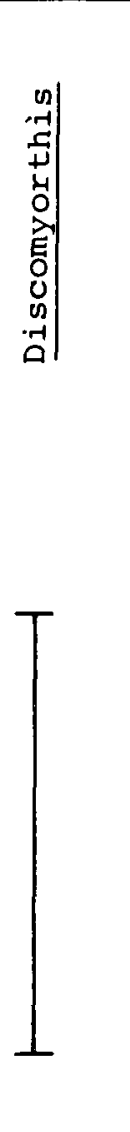 } \\
\hline & & & & Cassadagan & & & & & \\
\hline & & \multirow{2}{*}{ Frasnian } & & Chemungian & & & & & \\
\hline & & & & Fingerlakesian & & & & & \\
\hline & \multirow{2}{*}{$\begin{array}{l}\text { 品 } \\
\text { 合 } \\
\text { 量 }\end{array}$} & Givetian & \multicolumn{2}{|r|}{ Hamilton } & & & & & \\
\hline & & Eifelian & & Onondaga & & & & & \\
\hline & \multirow{7}{*}{ 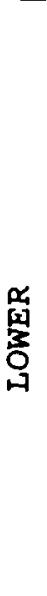 } & \multirow{3}{*}{ Emsian } & & Disconformity & & & & & \\
\hline & & & & Schoharie & & & & & \\
\hline & & & & Esopus & & & & & \\
\hline & & \multirow{2}{*}{ Siegenian } & & oriskany & & & & & \\
\hline & & & \multirow{3}{*}{ 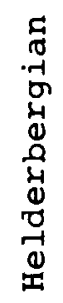 } & Becraft & & & & & \\
\hline & & \multirow{2}{*}{ Gedinnian } & & New Scotland & & & & & \\
\hline & & & & Manlius-Coeymans & & & & & \\
\hline
\end{tabular}

Figure 2 - Standard and American Sections of the Devonian, showing ranges of the Temiscouata Formation brachiopods.

lian) time interval, which makes the genus of far less value for dating the Temiscouata Formation. Discomyorthis (locality 9) has a known range of early Helderbergian through the Schoharie which is of use in helping to support an Early rather than Middle Devonian age. The large spiriferid which resembles Howellezla gaspensis (localities 7,9 and 10) is consistent with an Esopus or Schoharie age assignment.

Highly carbonized plant remains and one recognizable spore, tentatively Retusotriletes sp., were documented by D.C. McGregor of the Geological Survey of Canada from poorly preserved plant debris sent to him. McGregor (personal com- munication 1976) believes the Retusotriletes (locality 3) is certainly no older than Late Silurian and is probably not older than Devonian.

REGIONAL AGE OF THE SLATE FORMATIONS

Throughout the northern part of the Gaspé Trough, the Temiscouata Formation and correlated slaty rocks overlie a variety of Devonian, Silurian and pre-Silurian formations. The age of the basal slate beds has been well-established in two locations. Firstly, by the southeast margin of the Trough at Fish River Lake in northern Maine, the contact between the Seboomook Formation and the 
underlying Fish River Lake Formation is exposed and seen to be conformable. Just below the basal Seboomook, on the west shore of Fish River Lake, an extensive assemblage of brachiopods estabIish a New Scotland (middle Helderbergian) age for the upper beds of the Fish River Lake Formation (Boone 1970). Secondly, in the Moose River Synclinorium, $200 \mathrm{~km}$ to the southwest of $\mathrm{Fish}$ River Lake, the basal beds of the Seboomook Formation contain Atrypina sp., Spinoplasia gaspensis, orthostrophia ef. o. strophomenoides, and Levenea ef. L. subcarinata suggesting a New Scotland age (Boucot and Heath 1969).

A coral-bearing limestone bed at Rivière Bleue, about $25 \mathrm{~km}$ southwest of Lake Temiscouata, has in the past been used to date the base of the Temiscouata Formation (cf. Lajoie et al. 1968). The limestone bed occurs near the base of the "Temiscouata Formation" and contains Tryplasma ef. T. Zoveni and Halysites, indicating a Silurian age. The Rivière Bleue rocks apparently strike to the southwest, where only $6 \mathrm{~km}$ away in northern Maine they merge with Siluro-Devonian strata that Boudette et al. (1976) correlated not with the Temiscouata Formation, but with the Upper Silurian Mount Wissick Group.

In the past, rocks along the central part of the Devonian slate belt were dated as no younger than mid Lower Devonian (Becraft-oriskany) primarily on the presence of Leptocoelia flabellites. Until recently, later Lower Devonian fossils were unrecorded in the slates. However, the presence of Eodevonaria and Plicanoplia now allows the age of the slates to be extended upward into the late Lower Devonian (Esopus or Schoharie). New information has also arisen from more careful consider- ation of the brachiopods previously assigned in the Appalachians to Leptocoelia flabeliites. In the past this species was thought to indicate a mid Lower Devonian (Becraft-oriskany) age for the enclosing Temiscouata slates. Although found chiefly in beds of Oriskany (late siegenian) age, it was thought that Leptocoelia was present throughout older Lower Devonian beds in the central and northern Appalachians. Recently, however, Boucot and Rehmer (1977) have reviewed the occurrences of Leptocoelia and Pacificocoelia in eastern North America. They find that Leptocoelia is restricted to beds of Oriskany and Esopus age but that Pacificocoelia ranges from the mid-Helderbergian well into the Onondaga (Fig. 2). Prior to 1975 when Boucot (1975) separated the genus Pacificocoelia from Leptocoelia it was unfortunately common practice in the northern Appalachians to assign almost every leptocoelid brachiopod to Leptocoelia and even to $L$. flabellites. Therefore, occurrences of L. flabellites reported prior to 1975, and used as justification for a Becraft-oriskany age, should be reviewed if they have not been included in the list of occurrences included in Boucot and Rehmer (1977). For example, L. flabellites reported from the seboomook Formation near Fort Kent, Maine (Nylander 1940) can no longer be accepted, particularly now that Pacificocoelia is known in the nearby Temiscouata Formation at localities 5 and 8 (Fig. 1 and Table 1).

Some further confusion has arisen regarding the upper age limit of the Temiscouata slates. On the northwestern margin of the Gaspé. Trough, fossiliferous shallow water Middle Devonian (Onondaga) limestones were believed to stratigraphically underlie the much 
deeper water flyschoid slates (Lespérance and Greiner 1969, p. 82). These limestones (the Mountain House Wharf Limestone in the Lake Memphremagog area, the Famine Limestone in the lake Etchemin area, and the Touladi Limestone in the Lake Temiscouata area) are now known to be overthrust by the older Temiscouata slates (Lespérance and Greiner 1969,p. viii; St. Julien and Hubert 1975). Thus, the most reliable fossil dates indicate that the Temiscouata Formation and correlatea slates range from basal beds of New Scotland (late Gedinnian) age to upper beds of Esopus or Schoharie (early or middle Emsian) age.

The newly discovered Temiscouata brachiopods establish a lower age for penetrative Acadian deformation within northwestern New Brunswick as Esopus or Schoharie ( $c f$. Donohoe and Pajari 1974).

\section{SUMMARY}

The basal beds of the Temiscouata Formation are assigned a Helderbergian (New Scotland) age for the following reasons: 1- The formation conformably overlies the Perham Formation, the upper beds of which can be correlated with the Ludlovian to Siegenian(?) Fogelin Hill Formation in Maine. 2- Correlated slates of the seboomook Formation in Maine conformably overlie the Fish River Lake Formation, the latter bearing New Scotland age brachiopods in its upper beds. 3 - the basal beds of the Seboomook Formation in the Moose River Synclinorium in Maine contain a brachiopod assemblage suggesting a New Scotland age.

The discovery of two new brachiopod genera in Madawaska County Eodevonaria and Plicanoplia - indicates that the Temiscouata Formation ranges upwards into the Esopus or Schoharie (early to mid- dle Emsian). The taxonomic reclassification of Leptocoelia flabellites is cited as supporting evidence for the Emsian age assignment.

\section{ACKNOWLEDGEMENTS}

We are grateful to J. Béland and J.P.A. Noble for their critical review of the original manuscript. C. St. Peter extends thanks to L.R. Fyffe for encouragement that led to the completion of the paper. Diane Blair kindly typed the manuscript and Ronald Phillips drafted the diagrams.

BÉLAND, J. R. 1957. St. Magloire and Rosaire-St-Pamphile Areas, Electoral Districts of Dorchester, Bellechasse, Montmagny, and L'Islet. Quebec Department of Mines, Geology Report 76, 49p.

BOONE, G.M. 1970. The Fish River Lake Formation and its environment of deposition. In Shorter Contributions to Maine Geology, Bulletin 23, pp. 27-41.

BOUCOT, A.J. 1968. Silurian and Devonian of the Northern Appalachians. In Studies of Appalachian Geology (Northern and Maritime), Edited by E-An Zen et al., Interscience Publishers pp. 8395.

1970. Devonian slate problems in the Northern Appalachians. In Shorter Contributions to Maine Geology, Bulletin 23, pp. 42-48.

1975. Evolution and Extinction Rate Controls. Elsevier, 427p.

BOUCOT, A.J. and HEATH, E.W. 1969. Geology of the Moose River and Roach River Synclinoria, northwestern Maine. Maine Geological Survey, Bulletin No. $21,117 \mathrm{p}$.

BOUCOT, A.J. and REHMER, J. 1977. Pacificocoelia acutiplicata (Conrad 1841) (Brachiopods) from the Esopus Shaie (Lower Devonian) of eastern New York. Journal of Paleontology, 51, pp. 11231132 . 
BOUDETTE, E.L., HATCH, N.L. Jr. and HARWOOD, D.S. 1976. Reconnaissance Geology of the upper St. John and Allagash River Basins, Maine. United States Department of the Interior, Geological Survey Bulletin 1406, 37p.

DONOHOE, H.V. Jr. and PAJARI, G.E. 1974. The age of the Acadian Deformation in Maine-New Brunswick. Maritime Sediments, 9, pp. 78-82.

HALL, B.A., POLLOCK, S.G., and DOLAN, K.M. 1976. Lower Devonian Seboomook Formation and Matagamon sandstone. northern Maine: A Flysch Basin-Margin Delta Complex. Geological Society of America, Memoir 148, pp. 57-63.

HAMILTON-SMITH, T. 1970. Stratigraphy and structure of Ordovocian and Silurian rocks of the Siegas area, New Brunswick. New Brunswick Department of Natural Resources, Mineral Resources Branch, Report of Investigations No. 12, 55p.

LAJOIE, J., LESPÉRANCE, P.J. and BÉLAND, J. 1968. Silurian stratigraphy and paleography of Matapedia-Temiscouata regjon, Quebec. The American Association of Petroleum Geologists Bulletin, 52, pp. 615-640.

LESPÉRANCE, P.J. and GREINER, H.R. 1969. Squatec-Cabano area: Rimouski, Rivière du-Loup and Temiscouata Counties, Quebec. Quebec Department of Natura1 Resources, Mines Branch, Geological Report 128, 111p.

McGERRIGLE, H.W. 1934. Western Temiscouata with parts of Kamouraska and Rivière-du-Loup Counties. Report of Minister Mines, Province of Quebec 1933, Part D, pp. 93-128.

McGREGOR, D.C. 1976. Temiscouata Formation Palynofossils. Geological Survey of Canada, Report No. F1-1976-DCM.

NYLANDER, 0.0. 1940. Geological Formations of the St. John River valley, northern Maine and New Brunswick. Privately printed paper, Caribou, Maine.
POOLE, W.H. 1967. Tectonic evolution of Appalachian region of Canada. In Geology of the Atlantic Region, Hugh Lilly Memorial Volume; The Geological Association of Canada, Special Paper No. 4, pp. 9-51.

1976. Plate tectonic evolution of the Canadian Appalachian region. Geological Survey of Canada, Paper 76-1B, pp. 113-126

RICKARDS, R.B. 1976. Graptolites from New Brunswick. Geological Survey of Canada, Report No. 0-2-1976-WID/RBR.

ROY, D.C. and MENCHER, E. 1976. Ordovician and Silurian stratigraphy of northeastern Aroostook County, Maine. Geological Society of America, Memoir 148, pp. 25-52.

SKIDMORE, W. B. 1965. Honorat-Reboul area, Bonaventure County, Quebec Department of Natural Resources, Geological Report 107, 30p.

1967. Geological map of Gaspé Peninsula. Geological Exploration Service, Quebec Department of Natura1 Resources, Map 1642.

ST. JULIEN, P. and HUBERT, L. 1975. Evolution of the Taconian Orogen in the Quebec Appalachians. American Journal of Science, 275-A, pp. 337-362.

ST. PETER, C. 1978. Geology of parts of Restigouche, Victoria and Madawaska Counties, northwestern New Brunswick. New Brunswick Department of Natural Resources, Mineral Resources Branch, Report of Investigations 17, 69p.

WILLIAMS, H. 1978. Tectonic lithofacies map of the Appalachian Orogen. Department of Geology, Memorial University of Newfoundland, Map No. 1.

$$
\begin{aligned}
& \text { Received: July 13,1981 } \\
& \text { Accepted: July 17, } 1981 \\
& \text { Reviewers: J. Béland } \\
& \text { J.P.A. Noble } \\
& \text { R.K. Pickerill }
\end{aligned}
$$

